\title{
THEORY OF INVENTIVE PROBLEM SOLVING (TRIZ) - APPLICATION AND IMPACT ON INNOVATION
}

\author{
Piotr KARENDAE \\ Novismo, Warsaw; Silesian University, Katowice; piotr.karendal@novismo.com
}

\begin{abstract}
This paper presents primary assumptions, origins and development of the Theory of Inventive Problem Solving (TRIZ) methodology. It also presents global application of the methodology and its impact on innovation by presenting original research into the interrelation between TRIZ implementation in a company and the increase in the number of patents obtained. Furthermore, it deals with the growing interest in TRIZ in Poland, and it describes events related to that.
\end{abstract}

Keywords: Theory of Inventive Problem Solving, TRIZ, innovation.

\section{The Theory of Inventive Problem Solving}

The Theory of Inventive Problem Solving (TRIZ) was developed by the Soviet inventor Henry Altshuller (1926-1998) who had devoted all his life to its development and improvement ${ }^{1}$. Although there is some disagreement as to the very beginnings of TRIZ, it is assumed that it was created in the. 1950s (Ikovenko, Yatsunenko, Karendał, Przymusiała, Kobyakov, Obojski, and Vintman, 2017, p. 11). Altshuller, while being employed at the Fleet Patent Office headquartered in Baku, through examination of the local patent collections discovered that both ways of creating new inventions and the number of issues arising in the course thereof are not infinite. What is more, it is possible to describe 'typical' problems mankind had faced throughout its development, and 'typical'" ways of resolving them in a relatively small number of ways. According to Altshuller, the entire surrounding world may be described as coexistence of two types of systems: natural (biological) systems and technological cal systems. Natural systems ought to be interpreted as anything created without human intervention, whereas technological systems ought to be interpreted as human creations only. However, it does not only mean technology per se, but also such elements as social organisation, or even science (Karendal, 2016, p. 154). Those were not the only laws

\footnotetext{
${ }^{1}$ More information on Henry Altshuller can be found on the site of the International TRIZ Association at: https://matriz.org/about-matriz/about-founder/, 10.10.2017.
} 
discovered by Altshuller. When conducting an extensive patent analysis, he realised all technological systems developed according to objectively existing principles, the so-called Technological System Development Principles, which needed to be rediscovered and used to develop technology and innovative tasks in a conscious manner (Altshuller, 1983, p. 35-39). Owing to the knowledge thereof, and the possibility to determine individual stages of technological systems development, it had become possible to forecast development thereof as well as to predict - in the case of technology - when a system marketing would permit the largest profit.

The TRIZ methodology as such was not confined to the foregoing discoveries. As any technological system, it also develops and evolves. At its initial stage of development, it aimed to develop an algorithm enabling technological problem solution. However, it was soon discovered that the problem solved was actually not the one to be solved. Much effort was thus put into developing tools which would enable identification of the problem that actually resulted in project failures. Upon the collapse of the Soviet Union and methodology migration to developed free market economies, TRIZ development was focused on development and application of tools enabling most efficient problem solution and product marketing. On the other hand, its latest development has focused on further product improvement. Contemporary TRIZ has become a most extensive and comprehensive methodology of pragmatic innovations, i.e. innovations benefitting their creators. Historical development of the TRIZ methodology has been presented in the following figure.
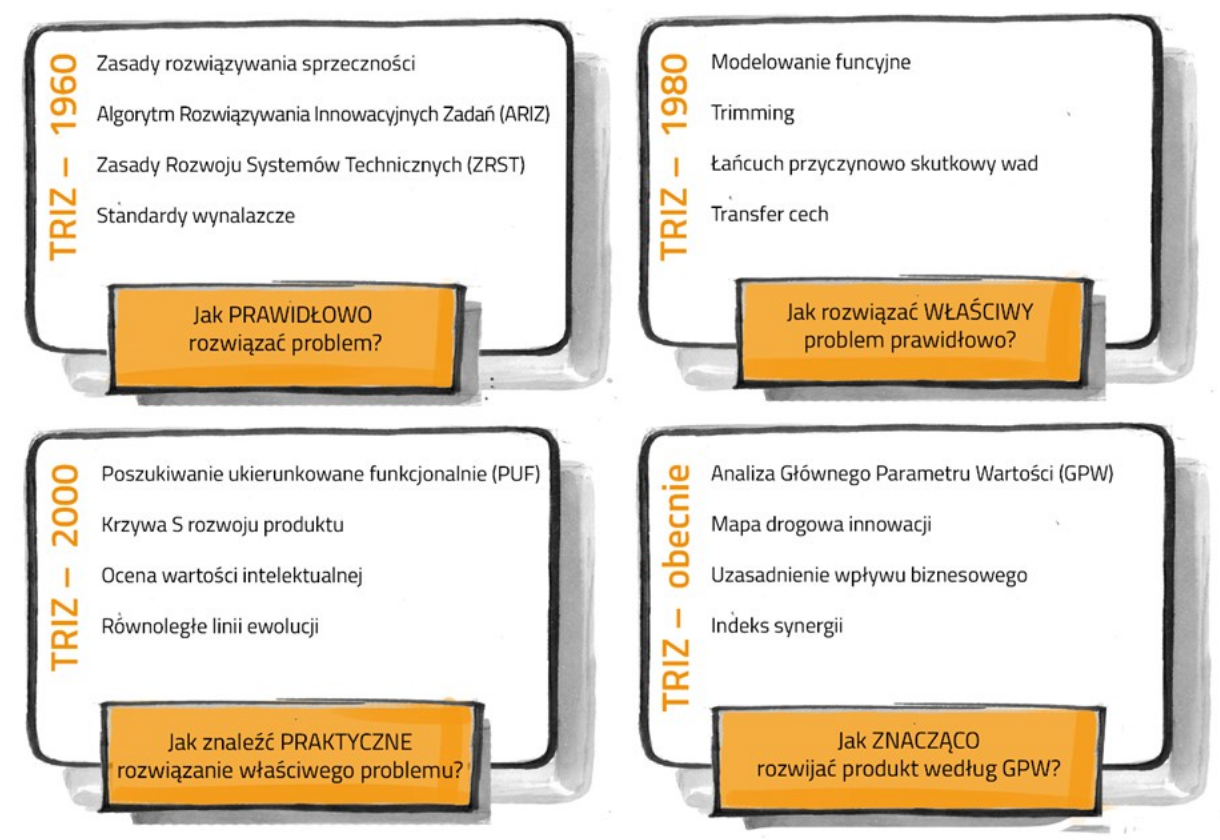

Figure 1. TRIZ development. Adapted from: "Współczesna Teoria Rozwiązywania Innowacyjnych Zadań. Podręcznik na I stopień certyfikacji Międzynarodowego Stowarzyszenia TRIZ (MA TRIZ)" by S. Ikovenko, S. Yatsunenko, P. Karendał, M. Przymusiała, S. Kobyakov, J. Obojski, Z. Vintman. Copyright 2017, p. 11. 
TRIZ systematics has become a very important aspect of its contemporary methodology. No chaotic actions are conducted, and innovations are developed through carefully planned and repeatable action based on an algorithm that covers three stages: problem identification, problem solving, and solution concept justification. Each of the foregoing stages plays a crucial role, and none of them may be disregarded. Also, all the stages involve sets of different tools enabling successful completion of innovative task individual phases. When commencing problem analysis, one ought to precisely identify project objectives and measurable results, and then, using TRIZ analytical tools, identify the main reasons for the inability to succeed. Identification of the problem, or problems, to be solved is followed by stage two which uses tools designed to solve problems. Their application results in a set of model solutions which still need to be transformed into actual ideas or projects. However, solution concept development is not the end of the actions. One still needs to evaluate and select the idea most likely to succeed in the market. The list of contemporary TRIZ tools is most extensive, but this ought not to be considered a flaw. All the tools are never simultaneously used on an innovative project. They are selected based on the type and objective of a specific project (Ikovenko, Yatsunenko, Karendał, Przymusiała, Kobyakov, Obojski, and Vintman, 2017, p. 22-23).

A full version of the TRIZ algorithm applicable to the foregoing stages has been presented below.

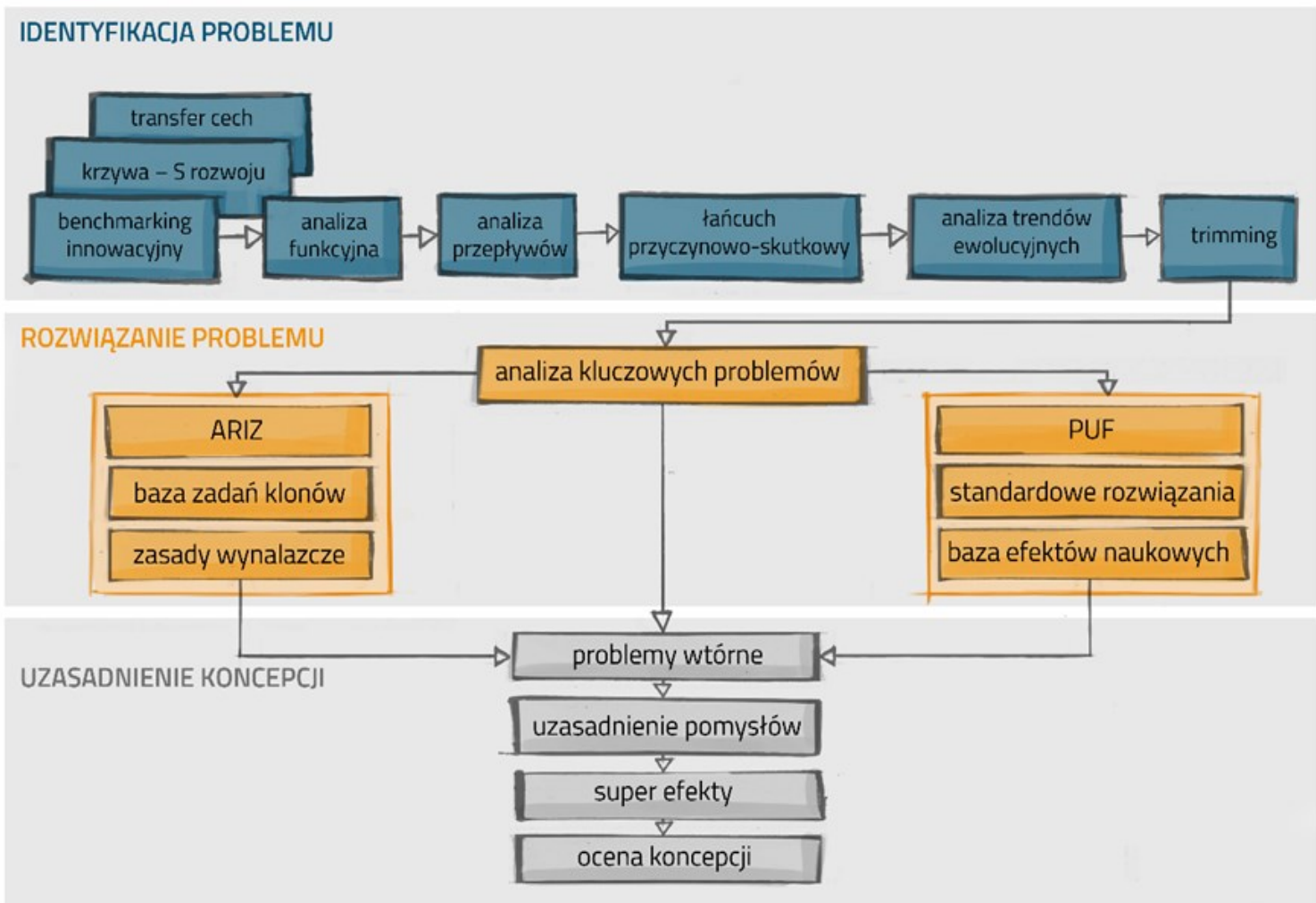

Figure 2. Pragmatic Innovation Roadmap. Adapted from: "Współczesna Teoria Rozwiązywania Innowacyjnych Zadań. Podręcznik na I stopień certyfikacji Międzynarodowego Stowarzyszenia TRIZ (MA TRIZ)" by S. Ikovenko, S. Yatsunenko, P. Karendał, M. Przymusiała, S. Kobyakov, J. Obojski, Z. Vintman. Copyright 2017, p. 24. 
With the development of the methodology and commencement of TRIZ popularisation outside the Soviet Union, there arose an idea of establishing an institution whose task would be to take care of the quality of the knowledge transferred as well as to set standards and new directions of development. For this reason, the International TRIZ Association (MA TRIZ) (https://matriz.org/about-matriz, 2017) was founded in 1997, and it soon became an institution bringing together all the most important TRIZ organisations from all over the world. Given that the methodology had been significantly extended, the entire TRIZ knowledge was divided by the International TRIZ Association into five levels. The first three levels of certification enable understanding and mastering of all the tools at the methodology's disposal. Knowledge is gained through training sessions conducted by MA TRIZ accredited trainers. Each of the first three stages concludes with a written examination; if one applies for a 3rd level certificate, they may be subject to an additional oral examination designed to verify the knowledge gained. Certification at the highest levels proceeds in a slightly different manner. In the case of the 4th level, one needs to demonstrate work with the methodology applied, they need to select and successfully complete a project, and they need to deliver it in written form to the MA TRIZ examination committee. If it receives a positive review, the applicant receives a 4th level certificate. However, one may not apply for this knowledge level certification without holding a 3rd level certificate. Obtaining the 5th level knowledge certificate and the TRIZ Master title requires the applicant's own contribution to the methodology development. However, a written paper shall not suffice. Before the applicant may obtain the highest level of methodology knowledge certificate, they need to defend their paper before a committee comprising other TRIZ Masters (https://matriz.org/matrizoffices/council-on-expertise-and-methodology-cem/certification/how-to-become-a-specialist, 2017). This is only possible once a year, during the TRIZ fest - the largest international TRIZ methodology meeting.

\section{TRIZ in the world}

At this point, it is worth asking how many specialists there are who can pride themselves on holding a TRIZ knowledge certificate granted by MA TRIZ. The foregoing diagram presents all the TRIZ certificates granted in the years 2008-2016 with respect to all the levels (https://matriz.org/matriz-offices/council-on-expertise-and-methodology-cem/certification/listsof-certified-triz-specialists, 2017). 4th and 5th level certificates have been shown together due to the insignificant number thereof as compared to the other certification levels. Another problem worth clarifying is also the analysis timeframe. Given that the 2017 data is incomplete (as at November 2017), a decision was made to present data up to 2016 included. 
As far as the analysis commencement date is concerned, it was related to the commencement of training activities on a large scale. Although 1st-3rd level certificates were granted before 2008, the official requirement that the certification date be entered in the MA TRIZ database had not been imposed until then. For that reason, a decision was made to select this very date. Similar is the case of higher level certificates which were also granted before 2008. For instance, Altshuller himself, before his death in 1998, granted his 65 students the highest obtainable certificates. However, in order to preserve data presentation continuity, while avoiding an excessive number of diagrams, a decision was also made to apply the original starting date of 2008 .

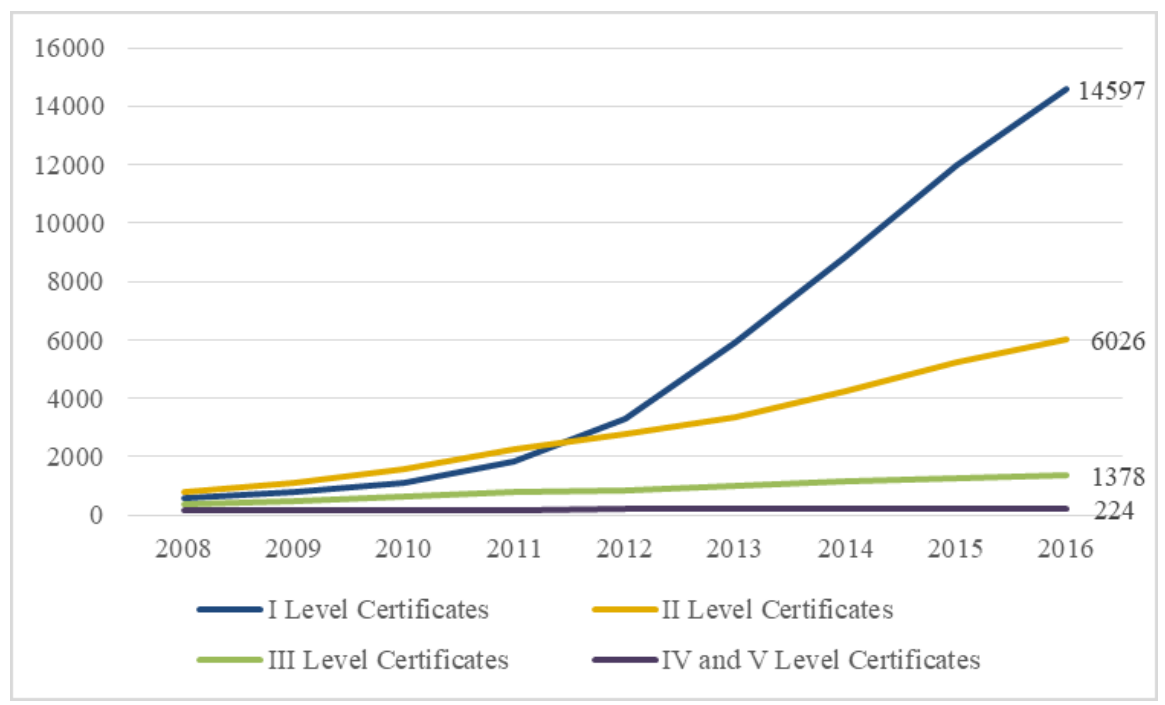

Figure 3. World I-V Level TRIZ certifications 2008-2016. Own study.

When analysing data on the number of TRIZ certifications, one may realise that the worldwide popularity of the methodology is a relatively new phenomenon. If the increase in the number of 1 st level certifications only is considered, it is clear that the interest in the methodology occurred after 2012. In just four years, the number of 1 st level certifications increased nearly fivefold. Similar was the situation in the case of 2 nd level certifications. Since the onset of the large-scale action commenced in 2012, their number had more than doubled. An increase, be it less significant, may also be observed in the case of 3rd level certifications. The situation with the highest level certification is different, due to the fact that they are difficult to obtain, the number of professionals who can pride themselves on holding such certifications is relatively low. However, this does not change the fact that the TRIZ methodology is beginning to transform from a relatively niche science of creating innovation to an increasingly more worldwide movement.

Given the increasing interest in the TRIZ methodology, it is worth asking what purpose it may be used for? Today, it may be applied to improve existing products or processes, but also to create and develop them. Owing to the above-mentioned technological system development principles, it may also be applied to develop a specific technology and to create strategies 
regarding intellectual property. It is also used to assess and verify technologies, and to identify reasons for incorrect operation of technologies. Moreover, it makes it possible to seek an adequate technology, very often - in most different fields. In recent years, it has started to be used with a view to future recycling of products developed, and to reuse of the materials used. Contemporary TRIZ is applied in numerous fields and industries. It is applied in the automotive, electronic, medical technology, optics and telecommunications industry, in the production and distribution of wide-ranging consumer goods, in the oil and energy industry, in the production and processing of metals.

\section{TRIZ vs. innovation}

There is no doubt that today innovation is one of the most important factors affecting global economic growth. It is because of that significant shift in the development paradigm the impact of which may be compared to the 18th century industrial revolution that the state (and - on a slightly lesser scale - the enterprise), capable of 'producing' knowledge on a large scale, may gain a crucial competitive advantage over others. It would be a huge mistake to ignore the global trend towards shifting from mass production in the so-called heavy industry to production and development of broadly interpreted technologies. Thus, growing popularity of any and all methodologies attempting to facilitate transition from the idea to the successful implementation thereof comes as no surprise.

However, it is worth asking whether the improvement idea is something completely new? It certainly isn't. What is more, there are plenty of well known creative thinking activation methods. There is no need to describe them in this paper as each reader will certainly come up with at least several of them (for instance brainstorming, analogies, or the morphological analysis). There are also more complex methodologies, for instance the Six Sigma methodology, or even a quality management philosophy - the Kaizen philosophy. All these methods and methodologies are popular throughout the world, and they are applied by the largest global enterprises. However, they are characterised by some inconvenience - they are mostly oriented at improving human skills, not the technology itself. What may it be considered a flaw? The answer is very simple: mankind evolves much slower than technology, so a method focused on technological development ought to be considered more efficient.

The need to 'focus on technology' is probably responsible for the rapid growth of interest in TRIZ all over the world. One of the TRIZ unique characteristics is the focus on development of technology and certain universal laws governing technological system evolution. TRIZ, which is also a system, has significantly developed since its formation in the 
1950s. Starting as a tool the overarching objective of which was to solve a problem, it has now become an extremely effective methodology enabling identification of the correct problem, its solution in the most efficient and practical way, and - most importantly marketing and sale of such a solution.

Although TRIZ has been around for decades, a very rapid growth of its popularity has been observed since relatively not long ago. In just three years since the statistical survey on the number of TRIZ certifications around the world (http://novismo.com/wiedza/artykuly/ ?article=triz_na_swiecie, 2017), carried out in August 2014, the number of certified TRIZ professionals has more than doubled (https:/matriz.org/matriz-offices/council-on-expertiseand-methodology-cem/certification/lists-of-certified-triz-specialists, 2017). The current number of officially certified professionals around the world (status as at November 2017) is more than twenty-four thousand. It is an excellent reason to investigate the impact of the TRIZ methodology on the creation of innovations.

The most important question is how widespread implementation of the TRIZ methodology may contribute to the increase of the innovation rate? So posed a question instantly brings about two serious problems. The first of them is innovation itself, measured today with numerous indicators. Given the imperfectness of the manner adopted, this analysis will pertain to the most general and most easily measured indicator, namely the number of patents which may be considered as official acknowledgement of the new knowledge produced. The other problem is as important: how many official certifications may be considered as general implementation within a specific country or enterprise? In order to overcome this adversity, a decision was made to focus on studies into one country only, namely South Korea (https://matriz.org/matriz-offices/council-on-expertise-and-methodology-cem/certification/listsof-certified-triz-specialists, 2017). The foregoing choice was not made by accident. If one were to name a country which has made TRIZ application one of the sources of its competitive advantages, they would need to name but the Republic of Korea. Almost $66 \%$ of the certificates of all degrees of knowledge are held by TRIZ experts from South Korea (https://matriz.org/matriz-offices/council-on-expertise-and-methodology-cem/certification/listsof-certified-triz-specialists, 2017), so it appears that it is the most appropriate country to carry out such an analysis. 


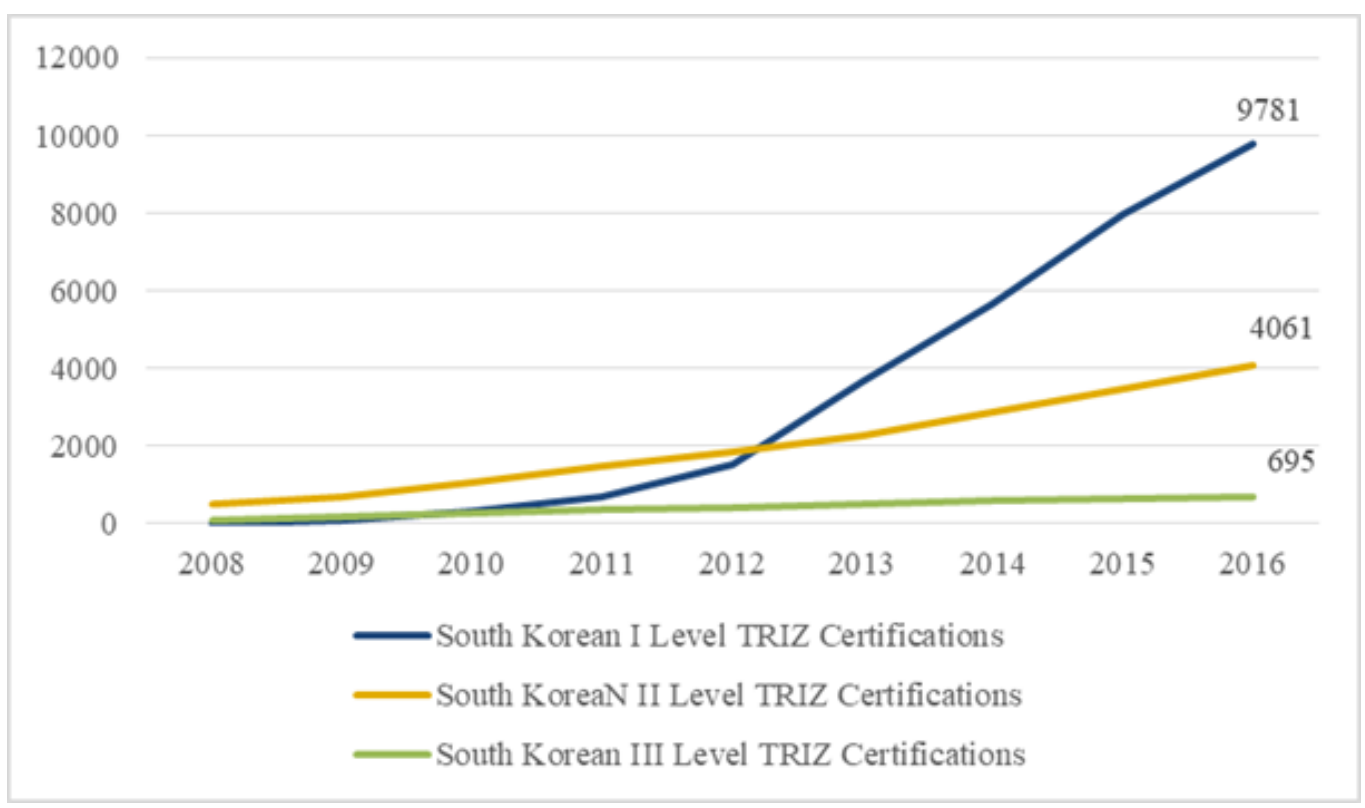

Figure 4. South Korean I-III Level TRIZ certifications 2008-2016. Own study.

The foregoing diagram shows the number of 1st-3rd level certifications obtained in South Korea in the years 2008-2016. However, in order to avoid possible misunderstanding, several issues need to be clarified. The analysis only covers the first three levels of the TRIZ certification. This is so due to the specifics of the very TRIZ training. All the methodology knowledge is obtained upon completion of the 3rd level training. Higher levels are obtained through independent work with the TRIZ methodology. Consequently, in order to measure the impact of TRIZ on innovation, it is worth focusing on professionals who have completed such training, and on their accomplishments. To some extent, this may reflect how TRIZ implementation may bring about results in a short time. What is more, the number of 4th and 5 th level professionals in South Korea is rather insignificant.

It has been possible to observe a sharp increase in the number of certified TRIZ professionals from the Republic of Korea since 2010. The number began to increase even more rapidly in 2012, and there continues to be a distinct growing trend. In 2016, South Korea could pride itself on having 9,781 1st level professionals, 4,061 2nd level professionals, and 6953 rd level professionals. How does this high number of certifications affect innovativeness of the country? As it has already been mentioned, further research - a patent statistics analysis - ought to be conducted for this problem to be measured. 


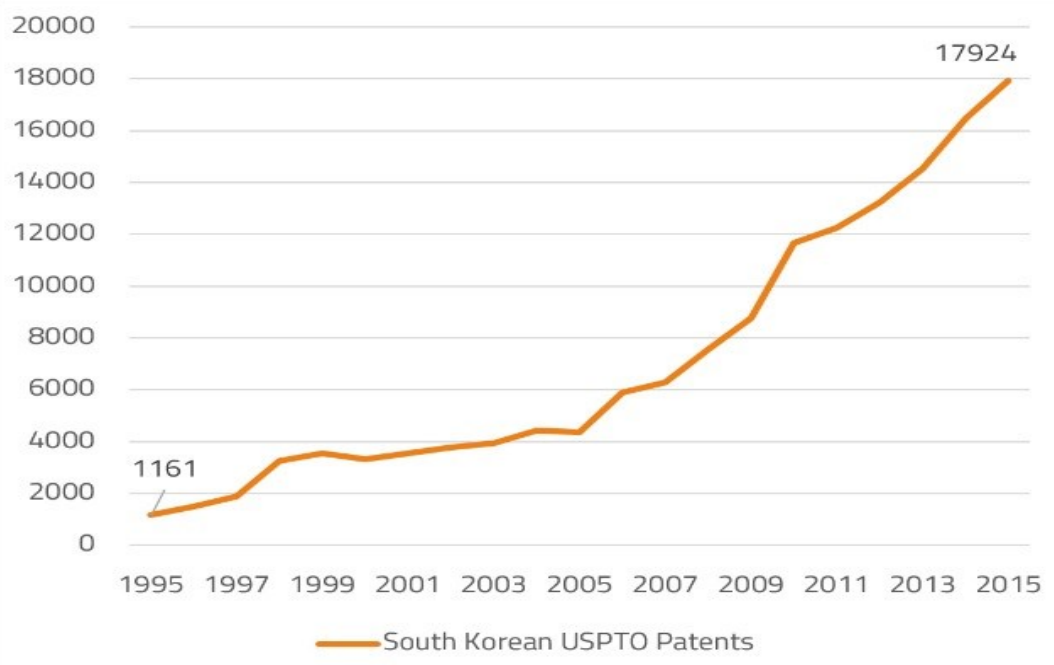

Figure 5. South Korean USPTO patents 1995-2015. Own study.

The foregoing diagram shows the number of South Korean patents registered by the United States Patent and Trademark Office (USPTO) in the years 1995-2015 (http://www.uspto.gov/web/offices/ac/ido/oeip/taf/reports.htm\#by_org, 2017). Selection of the database to be analysed ought to be clarified in this case as well. The main reason for the USPTO database selection was the position held by the United States within in the global economy - it is one of the largest markets in the world, and anyone who wants to be a major player in world economy needs to patent their solutions there. Another important factor was the detailedness of the data contained in the Patent Office of the United States database - not only does it cover patent activity of a specific country, but it also covers companies originating from individual countries, which will be of crucial importance further on in this analysis. As regards the timeframe of the analysis, similarly to the TRIZ certification, its beginning (1995) was dictated by the USPTO starting to make such statistics available, whereas 2015 was the last year in which such a collection of data was made available by the United States Patent Office (status as at November 2017).

In barely 20 years, South Korea recorded that the number of patents granted increased fifteen times - from 1,161 patent applications in 1995 to as many as 17,924 patent applications in 2015. Patent statistics clearly indicate how much the status of innovation changed in the Republic of Korea - it has become one of the most innovative countries in the world. When analysis the diagram more diligently, one may observe that the first stage of the increase could be observed back in 1997, with further and more distinct growing trends being observable in 2005 and 2007. On the other hand, it has been possible to observe an uninterrupted increase since 2010. 


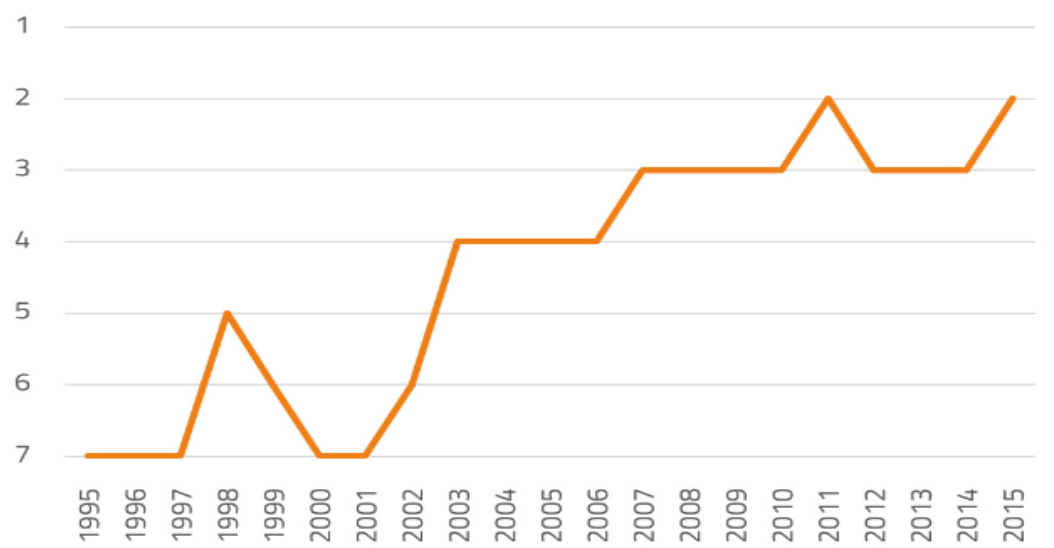

—South Korean USPTO Patent Rank

Figure 6. South Korean USPTO patent rank 1995-2015. Own study.

Given the foregoing patent rank, it may be observed that South Korea ranks second in terms of the number of patents granted in the United States.

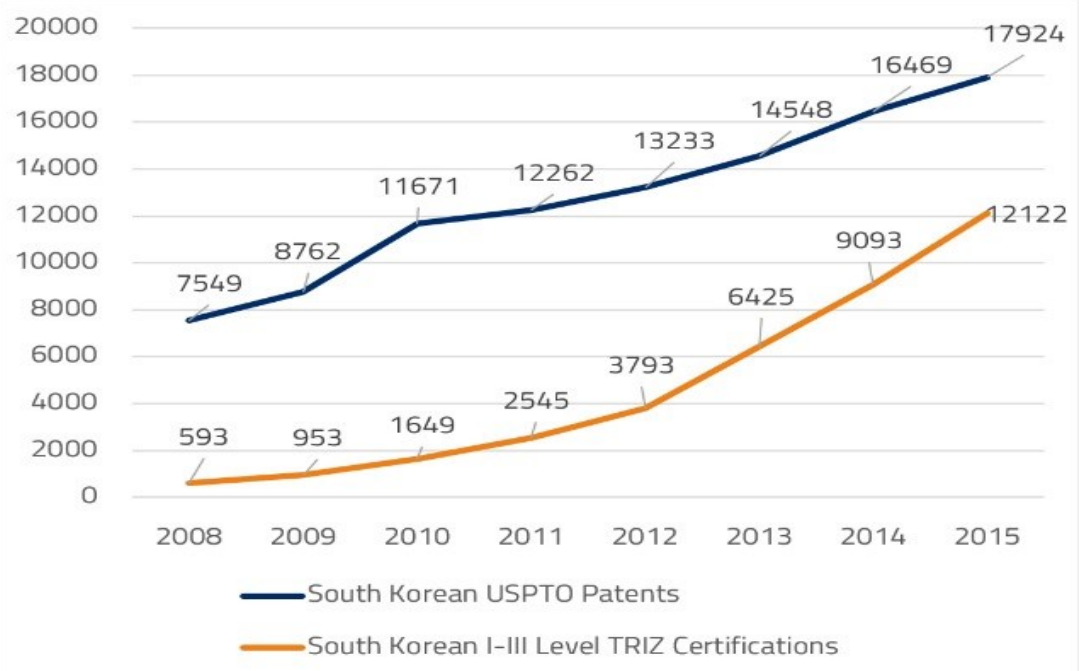

Figure 7. South Korean USPTO patents and I-III Level TRIZ certifications 2008-2015. Own study.

The foregoing diagram shows the correlation between the USPTO patents granted to South Korea and the number of TRIZ 1st to 3rd level professionals. It appears that the foregoing sharp increase in the number of patents granted may be attributed to the dynamic growth of the number of TRIZ professionals. As of 2010, we have been observing similarities between the growing number of TRIZ professionals and the number of USPTO patents obtained. Thus, a conclusion that there is a correlation between the two variables appears justified. However, it is worth noting that an analysis at the national level is definitely insufficient evidence - no country develops patent applications, or broadly interpreted innovations, just of its own accord. In order to understand what underlies the rapid growth of South Korean innovativeness, one needs to analyse its largest enterprises in a more in-depth manner. 
So as to analyse the phenomenon as deeply as possible, a decision was made to focus on the three largest and most popular Korean enterprises which had incorporated TRIZ in their corporate cultures, namely Samsung Electronics, LG Electronics and Hyundai Motor. Unfortunately, there is no data that describes the exact number and the increase in the number of TRIZ professionals in a given year, within individual enterprises; however, courtesy of the former President of MA TRIZ, Professor Sergey Ikovenko, it was possible to obtain information on the onset of TRIZ implementation within the aforementioned companies.

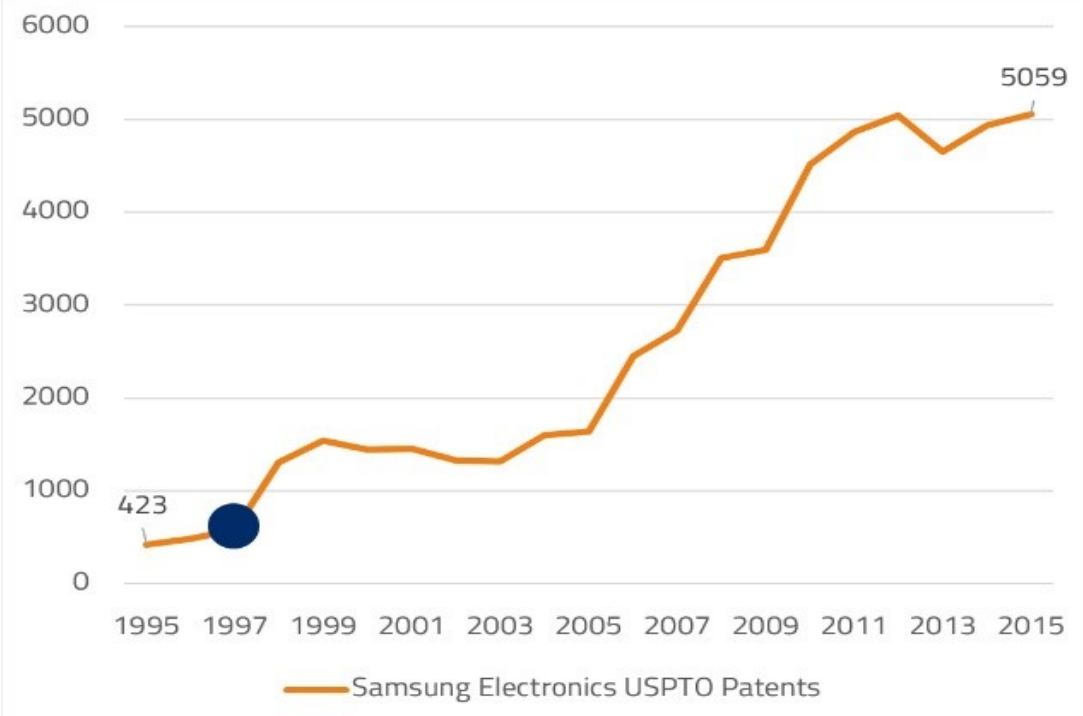

Figure 8. Samsung Electronics USPTO patents 1995-2015. Own study.

The foregoing diagram presents patents which Samsung Electronics obtained from the USPTO in the years 1995-2015. Similarly to South Korea, one may observe a huge growth of the number of patents granted in the period analysed. In that respect, Samsung recorded a nearly twelve-times increase - from 432 patents in 1995 to 5,059 patents in 2015. Patents obtained by Samsung Electronics from the United States Patent Office account for nearly 30\% of all the patents obtained from the Office by South Korea. Samsung was also the very first enterprise to implement the TRIZ methodology on a large scale. The first attempts were made back in 1997, which resulted in successful execution of a few original innovation projects. Since 1998, when TRIZ was actually implemented within Samsung Electronics (http://s828c8b.nubex.ru/file.php/id/f5767/name/6.\%20Article\%202.\%20The\%20Acceleration\%20of\%20 TRIZ\%20Propagation\%20in\%20Samsung\%20Electronics_ETRIA2005.pdf, 2017), the enterprise had recorded a significant, be it short-lasting, increase in the number of patents granted. Another, this time a very sharp and ongoing increase in the number of patents occurred after seven years. The gap was most probably related to the development of TRIZ itself - in recent years, a significant development thereof has been observed, and the methodology has become a tool enabling accomplishment of good results within a relatively short time. 


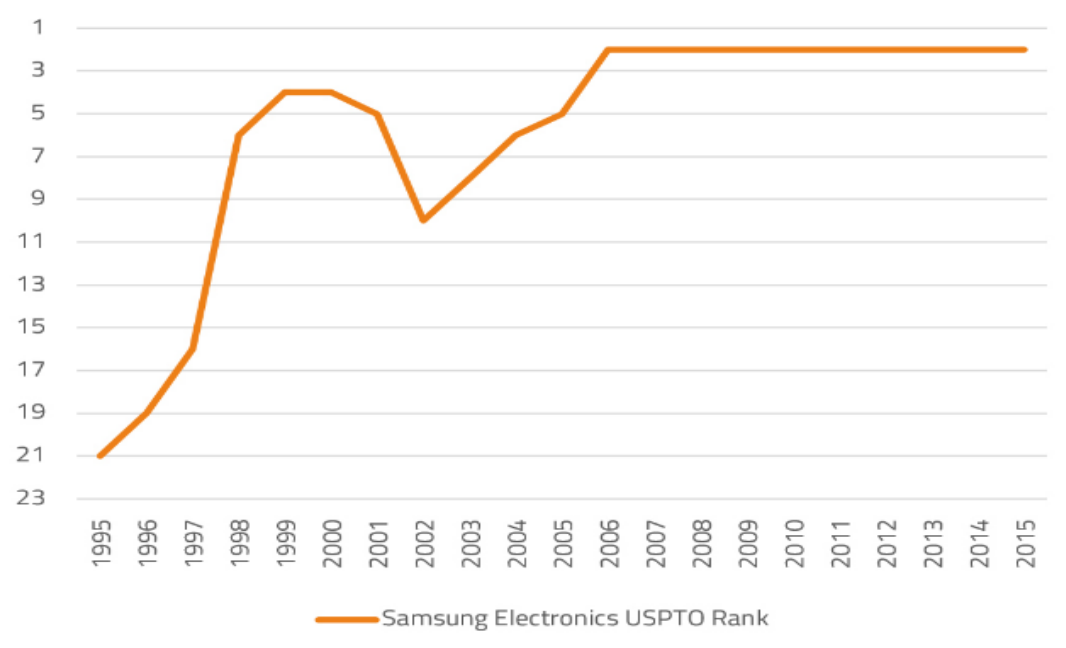

Figure 9. Samsung Electronics USPTO patent rank 1995-2015. Own study.

In order to illustrate the impact of TRIZ in the best possible manner, a decision was made to present the position held in terms of patents obtained by Samsung Electronics in the years 1995-2015; in the period analysed, the number increased much faster than within other enterprises. Starting as 21st in terms of the number of patents granted, since 2007 Samsung Electronics has ranked second, just after the American tycoon - IBM.

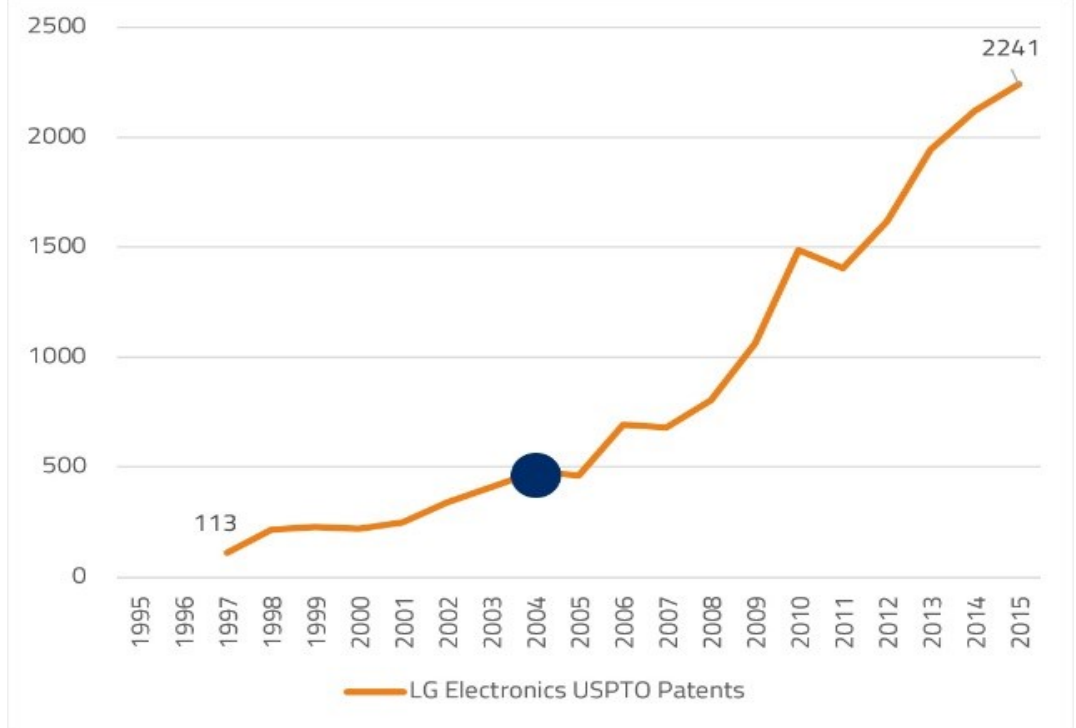

Figure 10. LG Electronics USPTO patents 1997-2015. Own study.

LG Electronics is a perfect example of the impact of modern TRIZ. Since TRIZ implementation commenced in 2004, the enterprise had recorded a most rapid increase in the number of patents granted by the USPTO - from 480 in 2004 to 2,241 in 2015. Today, patents obtained by LG Electronics account for $12 \%$ of all Korean patents granted by the United States Patent Office. The enterprise only required three years to commence such an intense growth. 


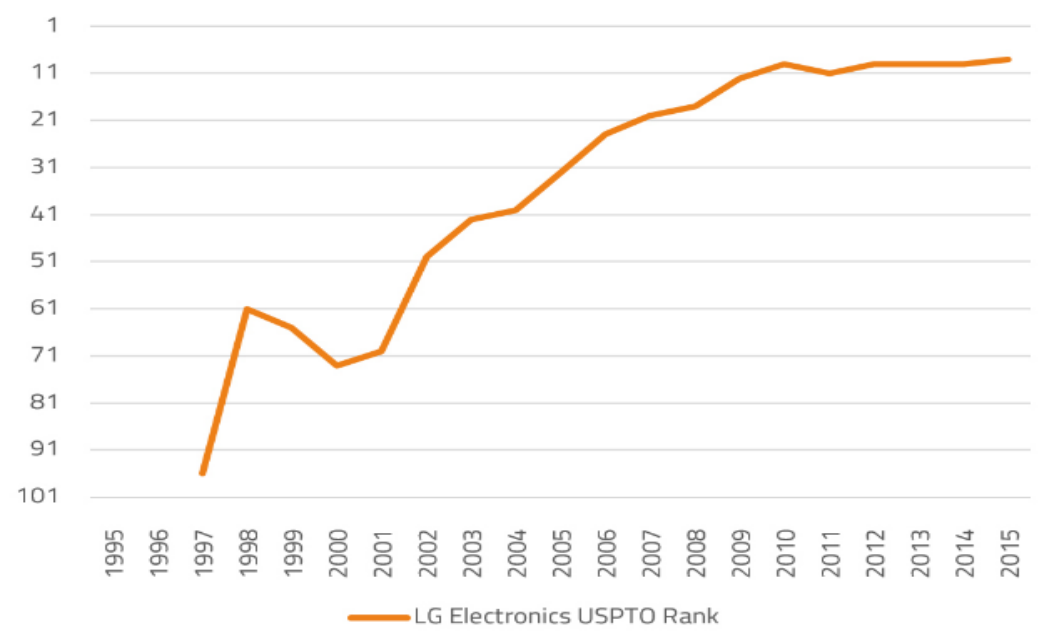

Figure 11. LG Electronics USPTO patent rank 1997-2015. Own study.

When LG Electronics commenced TRIZ methodology implementation in 2004, the USPTO ranked it the 40th in terms of the number of patents granted. A significant increase in their number over the period analysed led the enterprise to being ranked 9th in the statistics of the United States Patent Office in 2015.

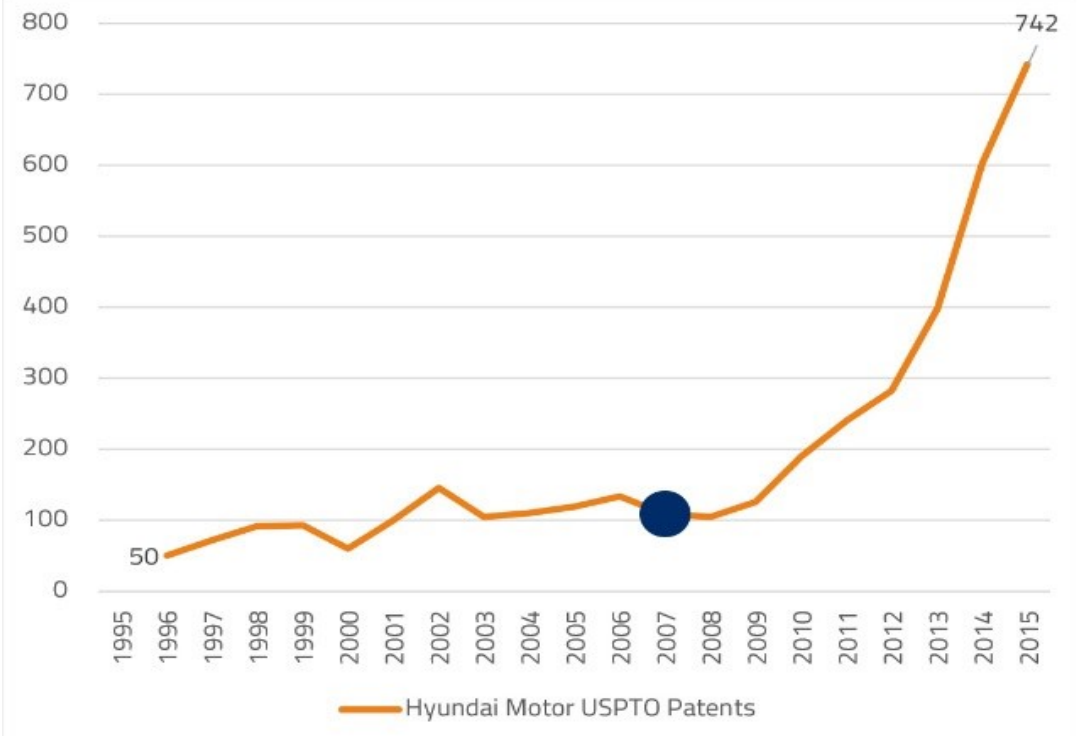

Figure 12. Hyundai Motor USPTO patents 1996-2015. Own study.

Another good example of the impact of TRIZ on corporate innovativeness is the situation of Hyundai Motor - the enterprise started with 109 patents at the time of implementation of the methodology in 2007, reaching 742 patents in 2015, which accounts for $4 \%$ of all Korean patents with the USPTO. The time required to observe the impact of TRIZ is even shorter - it took barely two years to observe a significant increase in the number of patents. 


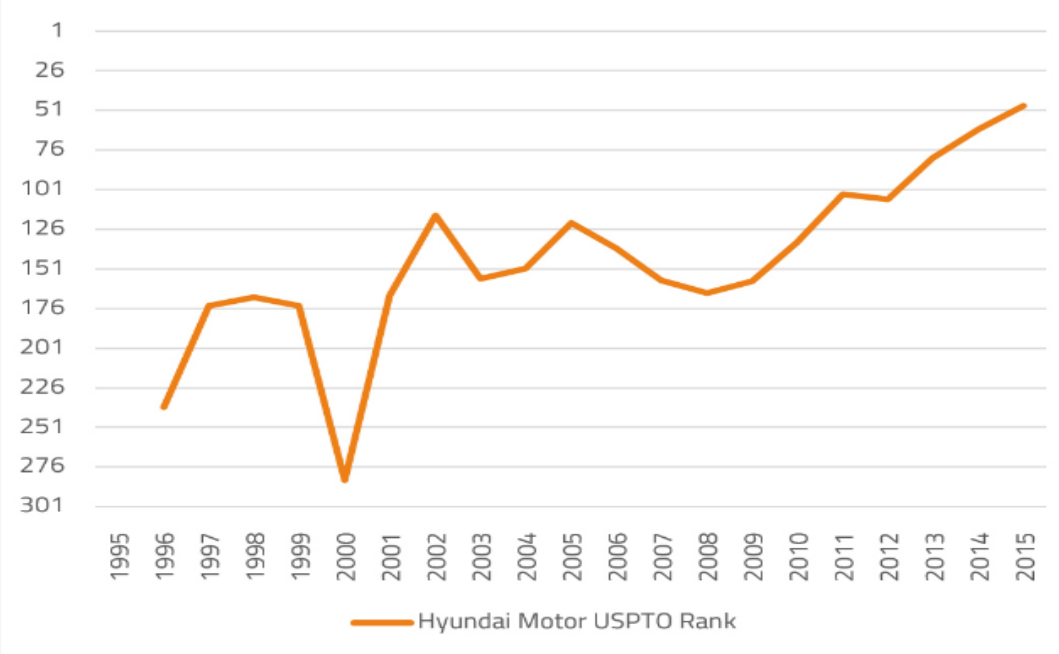

Figure 13. Hyundai Motor USPTO patent rank 1996-2015. Own study.

Hyundai Motor also followed the pattern of the previously analysed enterprises. At the time of TRIZ implementation in 2007, it was ranked 158th by the USPTO; after eight years, it was ranked 48th.

An analysis of the foregoing data shows that the correlation between South Korean enterprises that have implemented the TRIZ methodology and the growing number of their patents is relatively strong. TRIZ implementation appears to have a significant impact on their innovation rates. Interestingly, only three reported enterprises generate nearly half the patents obtained by South Korea from the USPTO. There is also one more dependency which it is worth highlighting. The fourth rapid increase in the number of patents appears to be linked to the growing number of TRIZ certifications. If one analysed the previous three rapid increases in the number of patents granted by the USPTO, they might observe they are closely linked to the dates of TRIZ implementation within individual Korean enterprises. This is a very interesting synergy.

The last factor worth analysing is how the growing number of patents may increase the value of individual brands. Eventually, innovations ought to provide their creators with profits. To that end, a decision was made to analyse Brand Finance Global 500 reports covering the years 2007-2015 (http://brandfinance.com/knowledge-centre/reports, 2017). The following diagrams illustrate changes in the brand value of Samsung, LG and Hyundai in the period analysed. 


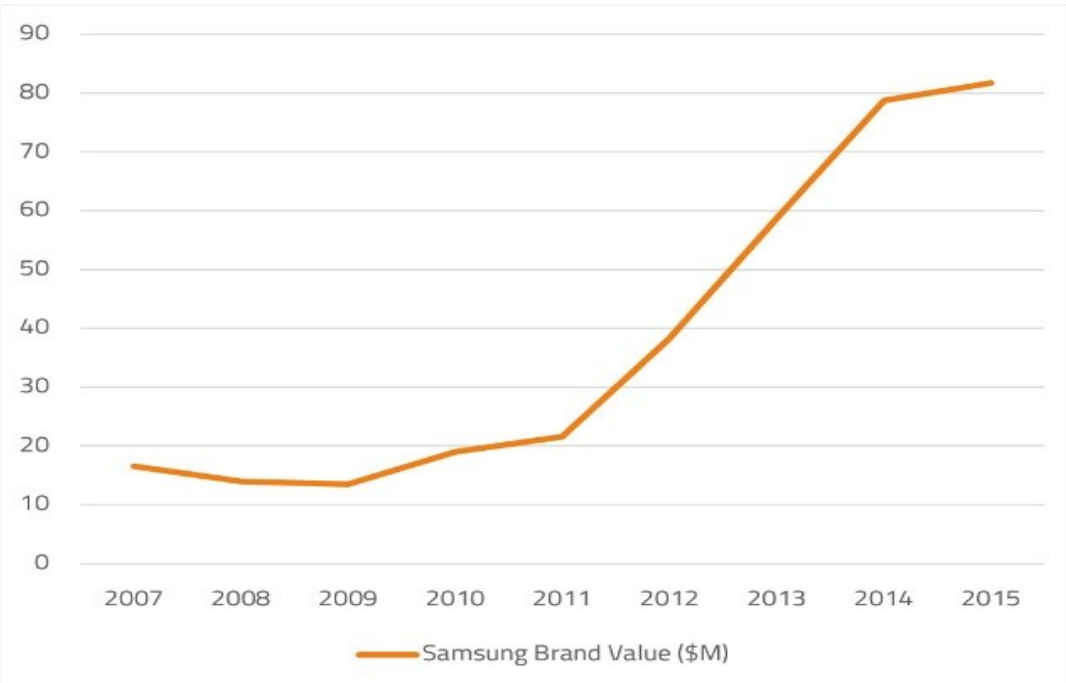

Figure 14. Samsung Brand Value (\$M) 2007-2015. Own study.

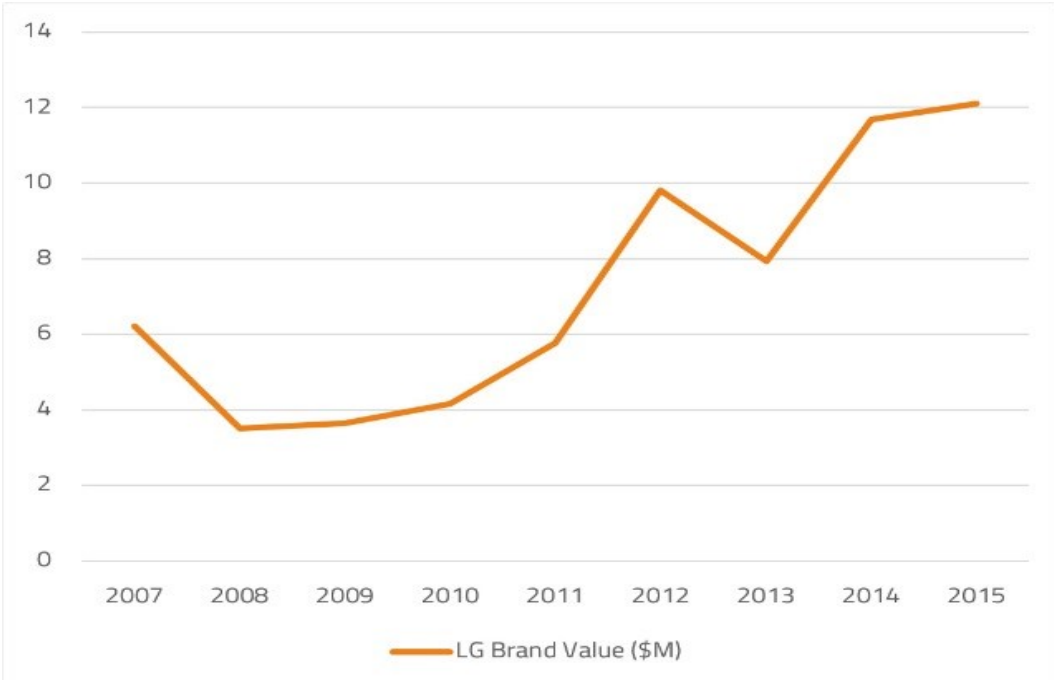

Figure 15. LG Brand Value (\$M) 2007-2015. Own study.

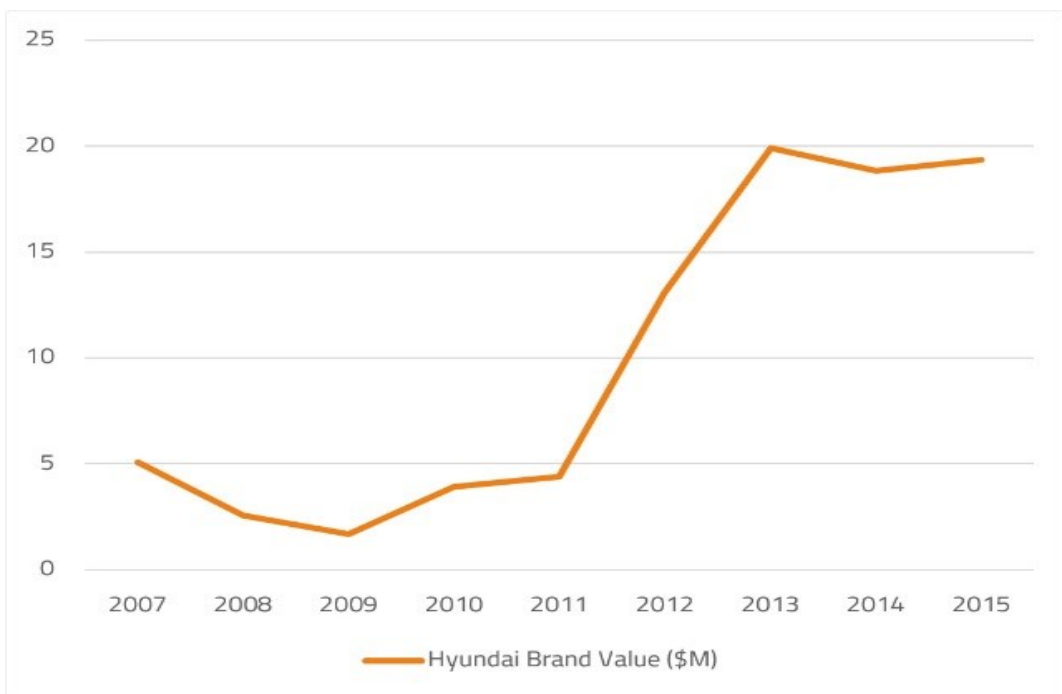

Figure 16. Hyundai Brand Value (\$M) 2007-2015. Own study. 
As it may be observed, the growing number of patents in linked to the increase in the brand value, in the case of Samsung and Hyundai in particular. However, one ought to be aware of the fact that this is not the only factor affecting the value of individual enterprises, yet responsible management, capable of using innovation as a source of competitive advantage, can contribute to a significant increase in the value of the enterprise concerned. It is also worth mentioning that TRIZ does not oppose other methodologies, Six Sigma or Kaizen in particular. They complement one another perfectly, and their concurrent application may contribute to accomplishment of even better results.

This analysis was aimed at demonstrating the impact of the TRIZ methodology on the rate of innovation of selected enterprises. Of course, it ought to be noted that patents themselves do not ensure an increase in the value of the enterprise - it also needs market success. However, given possible identification of the potentially best market solution through the application of the TRIZ methodology, implementation thereof may provide the enterprise with a significant competitive advantage.

\section{TRIZ in Poland}

Thus, it is worth asking a question about TRIZ popularity in Poland. Despite the geographical proximity, the methodology developed by Altshuller has never been popular here. Although the first books authored by the creator of TRIZ were published back in the 1970s (Altshuller, 1975), not many people have ever been convinced of its efficiency. For a very long time, activities related to the methodology promotion and teaching could be referred to as an 'unstructured phase'. There were occasional mentions or articles in magazines, but a more serious interest did not arise until the 21 st century. At that time, one could observe certain activities related to TRIZ educational activity, the first publications released in insignificant numbers of copies, or the very first projects and training sessions (Yatsunenko, Józwa, Karendał, Vintman, Przytuła, Boratyński, Boratyńska-Sala, and Stańczak, 2014, p. 269-272). This stage concluded with the granting of twenty 1st level certificates as well as by one of the TRIZ methodology implementation pioneers obtaining the 3rd level certificate in Poland back in 2013 (https://matriz.org/matriz-offices/council-on-expertise-andmethodology-cem/certification/lists-of-certified-triz-specialists, 2017). Aerfortis training company commencing its activities and conducting the first seminars on TRIZ at several enterprises and in the course of open meetings held back in 2014 was a harbinger of the increasing interest in the methodology. Those activities resulted in the formation of Novismo Group which significantly contributed to further growth of interest in the methodology in Poland. 
Since 2015, activities related to the TRIZ methodology promotion and implementation have become much more intense. It was back then that the-then President of MA TRIZ, Professor Sergei Ikovenko, invited by the Patent Office of the Republic of Poland, came to Poland for the very first time to give a series of lectures on the methodology. It was that same year that, at the initiative of Novismo and Świętokrzyskie Centrum Innowacji i Transferu Technologii, the TRIZ Poland Foundation was established, and it held the first in Poland international event related to the TRIZ methodology - the TRIZ Kick-off Meeting 2015 - to which they had invited to further best TRIZ professionals in the world to give their lectures. This made it possible to introduce the methodology to a wider audience, dominated by entrepreneurs.

Along the growing interest and, most importantly, demand for TRIZ knowledge in Poland, Novismo Group, working in collaboration with Professor Ikovenko, commenced a series of MA TRIZ official certification training covering TRIZ 1st and 2nd level of knowledge. The training comprised both closed series of lectures and workshops designed for enterprises ordering them, and open seminars for the public. This resulted in a rapid growth of the number of professionals who could pride themselves on holding MA TRIZ official certificates. The diagram below illustrates the increase in the number of $1 \mathrm{st}$, 2 nd and $3 \mathrm{rd}$ level certifications in Poland in the years 2012-2017. It is worth noting that the number of certifications in 2017 (status as at November 2017) ought to increase even further.

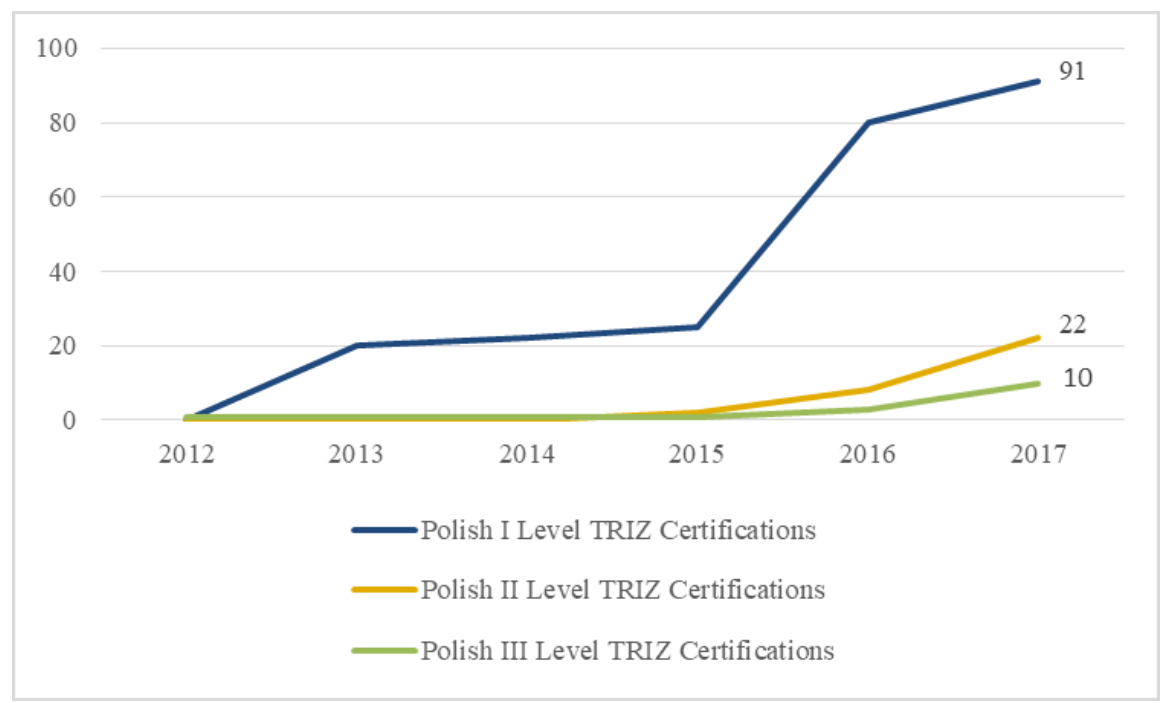

Figure 17. Polish I-III Level TRIZ certifications 2008-2017. Own study.

In barely two years, the number of Polish TRIZ professionals had increased nearly four times. When it comes to 2nd level professionals, the 2015-2017 statistics appear to be even more impressive: their number increased eleven times. Also, an increase in the number of 3rd level professionals is clearly visible; in 2017, there were as many as ten of them. What is interesting, the increase in the official number of TRIZ certifications in Poland, if slightly adjusted, is correlated to the dynamic growth of interested in the methodology all around the world. Although a lot more is required to reach the level of certification of South Korea, 
recent years have certainly brought about a significant increase which makes it possible to assume mass interest in the TRIZ methodology is yet to arise.

The increase in the methodology also results in the holding of international events related to TRIZ. Save for the already mentioned 2015 TRIZ Kick-off Meeting, Poland hosted two most important conferences on the TRIZ Methodology. In 2016, Wroclaw hosted TRIZ Future Conference 2016 - an international conference of TRIZ professionals, organised by the European TRIZ Association (ETRIA). A crowning achievement and recognition of the direction in which TRIZ had been developing in Poland was MA TRIZ granting the organisation of the most important methodology-related event - the TRIZ fest conference held in 2017 in Krakow. The event, held regularly throughout the world, attracted - just like every year - the most prominent TRIZ professionals from different continents to exchange their opinions and experiences related to practical TRIZ application. Organisation of the two largest events related to the European and the global TRIZ centres clearly shows that Poland is beginning to gain more and more respect and interest of the best TRIZ professionals in the world, which makes it possible to assume that with time Poland will join the group of countries applying TRIZ on a mass scale.

\section{Bibliography}

1. Altshuller, H. (1975). Algorytm wynalazku. Warsaw.

2. Altshuller, H. (1983). Elementy twórczości inżynierskiej, Warsaw.

3. Andrzejewski, G., and Jadkowski, K. TRIZ - metoda interdyscyplinarna. Retrieved from: http://www.knws.uz.zgora.pl/history/pdf/knws_05_andrzejewski_g.pdf.

4. Boratyński, J. Po co nam ten cały TRIZ? Retrieved from: http://www.pi.gov.p1/PARP/ chapter_86197.asp?soid=1DC767242FA04024BDD722D5D887EFA8.

5. http://brandfinance.com/knowledge-centre/reports/.

6. http://novismo.com/wiedza/artykuly/?article=triz_na_swiecie.

7. http://www.uspto.gov/web/offices/ac/ido/oeip/taf/reports.htm\#by_org.

8. https://matriz.org/.

9. Ikovenko, S., Yatsunenko, S., Karendał, P., Przymusiała, M., Kobyakov, S., Obojski, J., and Vintman, Z. (2017). Wspótczesna Teoria Rozwiąywania Innowacyjnych Zadań. Podręcznik na I stopień certyfikacji Międzynarodowego Stowarzyszenia TRIZ (MA TRIZ). Warsaw.

10. Jung-Hyeon, Kim, Jun-Young, Lee, and Sung-Wook, Kang. The Acceleration of TRIZ Propagation in SAMSUNG ELECTRONICS. Retrieved from: http://s828-c8b.nubex.ru/ file.php/id/f5767/name/6.\%20Article\%202.\%20The\%20Acceleration\%20of\%20TRIZ\%20 Propagation\%20in\%20Samsung\%20Electronics_ETRIA2005.pdf. 
11. Karendał, P. (2016). Teoria Rozwiazywania Innowacyjnych Zadań a gospodarka innowacyjna Korei Południowej. In J. Marszałek-Kawa, and M. Gołda-Sobczak (eds.), Polityczne i gospodarcze problemy współczesnej Azji. Torun.

12. Karendał, P., and Yatsunenko, S. Teoria Rozwiazywania Innowacyjnych Zadańkontrolowany sposób tworzenia innowacji. Retrieved from: http://www.pi.gov.pl/PARP/ chapter_86197.asp?soid=783A366A32434123A2D4E73FE0ABD076.

13. Shaughnessy, H. How Samsung Became Such a Formidable Competitor. Retrieved from: https://www.forbes.com/sites/haydnshaughnessy/2013/03/29/how-did-samsung-becomea-high-growth-company/\#6a0b8f1c55eb.

14. Shaughnessy, H. Samsung Gets Ahead Through Its Russian Connection. Retrieved from: https://www.forbes.com/sites/haydnshaughnessy/2013/03/13/samsung-gets-ahead-byusing-cheap-russian-science/\#b9b747c13e84.

15. Shaughnessy, H. What Makes Samsung Such An Innovative Company? Retrieved from: https://www.forbes.com/sites/haydnshaughnessy/2013/03/07/why-is-samsung-such-aninnovative-company/\#54a752272ad7.

16. Yatsunenko, S., Józwa, K., Karendał, P., Vintman, Z., Przytuła, P., Boratyński, J., Boratyńska-Sala, A., and Stańczak, I. (2014). The Strategy and Results of the Implementation of the TRIZ Methodology in Poland. In V. Souchkov, and T. Kässi (eds.), TRIZfest 2014. Theories and Applications. Conference Proceedings. Jablonec. 